\title{
Erupción polimórfica del embarazo
}

\section{Paulina Mariel Gay Muñoz, ${ }^{1}$ Sergio Oswaldo López Padilla ${ }^{2}$}

Primigesta de 24 años, cursando 38 semanas de gestación que inicia con presencia de prurito y eritema, pápulas y placas confluentes sobre estrías abdominales, con diseminación a miembros inferiores, respetando cara, palmas, plantas de los pies y mucosas. Recibió sólo emolientes, con parto sin complicaciones, las lesiones desaparecieron a las cinco semanas postparto. La erupción polimórfica del embarazo (EPE) es la segunda dermatosis más frecuente de éste; con incidencia de 1/160 embarazos, es benigna y se le observa más frecuentemente en primigestas durante el tercer trimestre o en el puerperio inmediato, se le asocia a un incremento importante del peso materno y en algunos casos existen antecedentes familiares. ${ }^{1}$ Se desconoce su etiopatogenia, se sabe que las células fetales o del trofoblasto que pasan a circulación materna estimulan la degranulación de los mastocitos; habitualmente los niveles de estrógenos y progesterona se incrementan y la progesterona empeora el proceso inflamatorio de la piel, por aumento en la inmunorreactividad del receptor de progesterona. ${ }^{2}$

Se caracteriza por erupciones polimorfas con pápulas de 1 a 2 mm que confluyen formando placas urticarianas, acompañadas de vesículas en menos de la mitad de los casos, también puede observarse púrpura y lesiones en diana (con halo pálido), todas las lesiones se acompañan de prurito que impide conciliar el sueño. Las lesiones mencionadas inician en las estrías abdominales o cicatrices previas, respetando el ombligo y se diseminan al tórax, las cuatro extremidades y nalgas, respetando cara, palmas, plantas y mucosas (Figuras 1 y 2). Los exámenes de laboratorio son normales, los hallazgos histopatológicos son inespecíficos.

\footnotetext{
${ }^{1}$ Medicina General. División de Medicina.

2 Dermatólogo. Jefe de la División de Medicina.
}

Hospital Ángeles León.

Correspondencia:

Dr. Sergio Oswaldo López Padilla

Correo electrónico: sergiolopezp@angelesleon.com

Aceptado: 02-12-2016.

Este artículo puede ser consultado en versión completa en http:// www.medigraphic.com/actamedica
En epidermis se observa: espongiosis, hiperqueratosis y paraqueratosis; en la dermis papilar: infiltrado linfohistiocitario perivascular; en los estudios inmunohistoquímicos el infiltrado se caracteriza por: linfocitos T cooperadores y

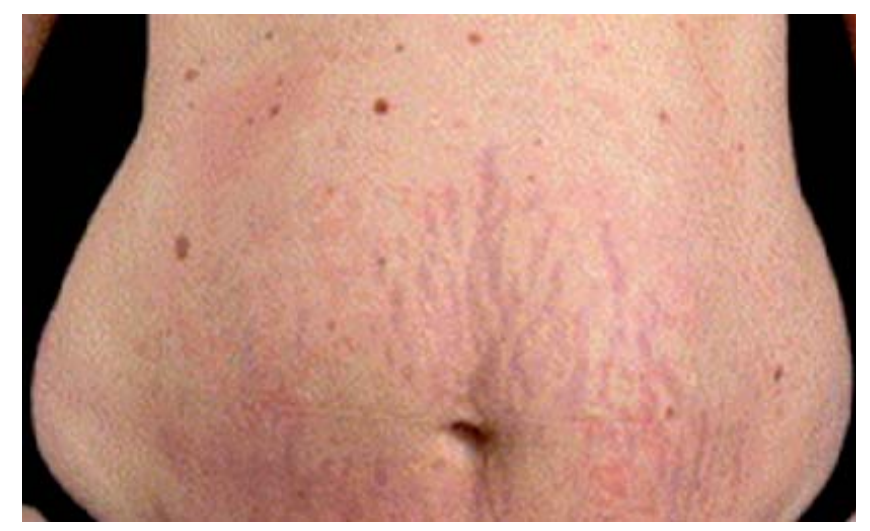

Figura 1. Primigesta de 24 años con presencia de dermatosis de inicio en la semana 38 de gestación, caracterizada por estrías en abdomen, asociadas a pápulas y placas urticarianas pruriginosas. Se llegó al diagnóstico de eritema polimorfo del embarazo.

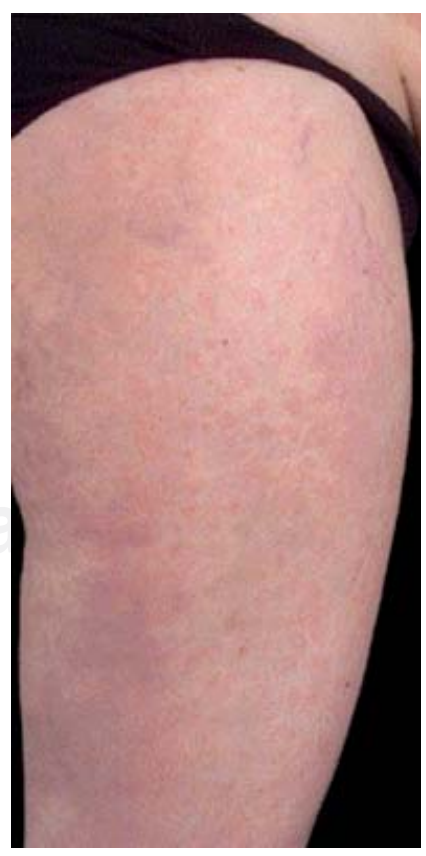

Figura 2.

Presencia de eritema, pápulas y placas urticarianas pruriginosas que abarcan miembros inferiores, las lesiones dérmicas desaparecieron cinco semanas postparto. 
aumento de CD1a+, CD54+, CD3+/CD45 Ro+, CD4+, CD8+, células dendríticas y células epidérmicas de Langerhans HLA DR+ y CD25+. En áreas perivasculares se encuentran células LFA-1 + CD11 a +/CD18+ asociadas a células dendríticas y células endoteliales ICAM-1+; lo que sugiere activación del sistema inmunitario cutáneo. ${ }^{3}$ El diagnóstico diferencial debe efectuarse con penfigoide bulloso gestacional, en la EPE la inmunofluorescencia es negativa, mientras que en el penfigoide bulloso gestacional la inmunofluorescencia directa confirma el diagnóstico con depósitos lineares de C3 con o sin IgG en la unión dermoepidérmica. La EPE es benigna, su duración es de aproximadamente seis semanas, no requiere tratamiento, el prurito tiene buena respuesta a los emolientes tópicos y moderadamente a esteroides tópicos de mediana potencia en combinación con antihistamínicos orales. En casos severos pueden administrarse esteroides sistémicos (pred- nisona a dosis de $0.5 \mathrm{mg}$-kg-día). En cuanto a pronóstico, la EPE se resuelve totalmente en el puerperio y no recidiva en embarazos subsecuentes, con excelente pronóstico maternofetal. ${ }^{4}$

\section{REFERENCIAS}

1. Matz H, Orion E, Wolf R. Pruritic urticarial papules and plaques of pregnancy: polymorphic eruption of pregnancy (PUPPP). Clin Dermatol. 2006; 24 (2): 105-108.

2. Rudolph CM, Al-Fares S, Vaughan-Jones SA, Müllegger RR, Kerl H, Black MM. Polymorphic eruption of pregnancy: clinicopathology and potential trigger factors in 181 patients. Br J Dermatol. 2006; 154 (1): 54-60.

3. Sirikudta W, Silpa-Archa N. Polymorphic eruption of pregnancy presented with targetoid lesions: a report of two cases. Case Rep Dermatol. 2013; 5 (2): 138-143.

4. Dehdashti AL, Wikas SM. Pruritic urticarial papules and plaques of pregnancy occurring postpartum. Cutis. 2015; 95 (6): 344-347. 